\title{
Multiple Myeloma in Cameroon: Clinico-Biological Characteristics of Patients; an Experience from Douala General Hospital
}

\author{
Ngouadjeu Dongho TE1,2*, Doualla MS1,3, Tolefac PN $^{3}$, Enow- \\ Orock $\mathrm{G}^{4}$, Oben DT ${ }^{4}$, Bihnwi $\mathrm{NR}^{4}$ and Mbanya $\mathrm{D}^{3}$ \\ ${ }^{1}$ Service of Internal Medicine and subspecialties, Douala General Hospital, \\ Cameroon \\ ${ }^{2}$ Faculty of Medicine and Pharmaceutical Sciences, University of Douala, \\ Cameroon \\ ${ }^{3}$ Faculty of Health Sciences, University of Buea, Cameroon \\ ${ }^{4}$ Faculty of Medicine and Biomedical Sciences, University of Yaoundé I, Cameroon
}

\section{Research Article \\ Volume 2 Issue 1}

Received Date: December 16, 2017

Published Date: January 02, 2018

DOI: $10.23880 / \mathrm{hij}-16000113$

*Corresponding author: Ngouadjeu Dongho Tsakeu Eveline, Douala General Hospital, BP 4658, Douala, Cameroon, Tel: 23796212836; E-mail: ngouadjeue@yahoo.fr

\section{Abstract}

Background: Multiple myeloma is the most common haematological malignancy among blacks. There is paucity of data on this subject in Africa in general and Cameroon in Cameroon. This study aims at describing initial clinical and basic laboratory features of multiple myeloma in Douala general hospital.

Methods: This was a retrospective cross sectional review of the medical records of all patients diagnosed with multiple myeloma in Douala general hospital between 2007 and 2013.

Results: A total of 62 patients were included in the study with an annual rate of 10-11 cases per annum. There was a female predominance with a male female sex ratio of $0.6: 1$ and a mean age of $57.6 \pm 12.2$ years. Clinical features at presentation were low back pain (72.6\%), and anemia (70.9\%), while neurologic impairment and nephropathy were found in $66.2 \%$ and $17.5 \%$ of the patients respectively. Most (63\%) of the patients were diagnosed at stage three of the disease at presented with already established complications.

Conclusion: Multiple myeloma is more common in our context than described in literature presenting in the 5th and 6th decades of life. Most patients present late with already established complications.

Keywords: Multiple Myeloma; Clinical; Biological Characteristics

Abbreviations: MM: Multiple Myeloma; MGUS: Multiple Gammopathy of Uncertained significance; DS: Dolie and Salmon Classification; IgG: Immunoglobulin G; IgA: Immunoglobulin A; DGH: Douala General Hospital

\section{Introduction}

Multiple myeloma (MM) is a neoplastic disorder which is characterized by proliferation of plasma cells, terminal derivative of $\mathrm{B}$ cells [1,2]. Multiple myeloma 
represents about $2 \%$ of all cancers and $10-12 \%$ of haematological malignancies [3]. It is the most common hematologic malignancy among blacks $[3,4]$. The aetiology of MM remains largely unknown [5], however, recent studies have identified the following factors implicated as potential risk factors of $\mathrm{MM}$, increasing age (>65 years), male gender, black race, positive family history of MM or LHC (genetic influence), and monoclonal gammopathy of undetermined significance (MGUS) [6,7]. MM is usually preceded by a MGUS at a progression rate of $1 \%$ per year [8]. The risk of progression from this premalignant conditions to MM is affected by the level of monoclonal immunoglobulin, the presence of nonIgG gammopathy, an abnormal serum free light-chain (sFLC) ratio, the fraction of bone marrow plasma cells bearing an aberrant phenotype, increased bone marrow plasma cells, decreased levels of polyclonal immunoglobulin, and aneuploidy [9]. The principal manifestations of multiple myeloma are as a result of the accumulation of malignant plasma cells in the bone marrow, with frequent invasion of adjacent bone producing skeletal destruction that results in bone pain and fractures, which are the commonest symptoms [10]. Classic clinical manifestations include hypercalcemia, renal failure, anaemia, and lytic bone lesions as well as recurrent bacterial infections and extramedullary soft-tissue plasmacytomas $[10,11]$. The CRAB criteria is now frequently used as diagnostic criteria for the diagnosis of multiple myeloma, and it constitutes symptoms such as raised calcium, renal impairment, anemia and bone pain [12].

Given the implications for future studies aimed at uncovering underlying susceptibility genes, it is important to define the clinical spectrum of MM. We conducted a comprehensive study designed to describe the clinical and biological characteristics of MM in Cameroon.

\section{Materials and Methods}

\section{Study Design and Setting}

Across sectional retrospective study was carried out in Douala general hospital (DGH) over a period of six years between January 2007 and December 2013. We include all patients diagnosed and managed in DGH for MM. DGH is a 1st category tertiary hospital located in the economic capital of Cameroon, Douala. It is one of the fastest growing hospitals in the central African sub region with a capacity of 320 beds. Among other units, it has a haematology unit with a clinical haematologist that receives and manages patients with MM.

\section{Data Collection}

Data was collected with the aid of case report forms. The following information was collected: sociodemographic characteristics, clinical presentations, laboratory investigations (such as immunofixation test, Bence Jones proteinuria, 24 hour proteinuria, serum levels of uric acid, urea, creatinine, hemoglobin levels e.t.c) and radiographic profiles (such as presence of lytic lesions, bone demineralization, spinal cord compression, e.t.c)

\section{Statistical Analysis}

This information was collected using epi info version 7 and analysed using SPSS version 20.0. We determined frequencies and percentages of categorical variables and means and standard deviations of continuous variables.

Ethical considerations: The principles of ethics in research involving human participants and the declaration of Helsinki were strictly respected. Ethical clearance was obtained from the institutional review board of the faculty of health sciences.

\section{Results}

\section{Sociodemographic Characteristics \\ and \\ Clinical}

Sixty two participants were included in the study. The mean age of the study participants was $57.6 \pm 12.2$ years with the majority of the participants $45-54$ years. There was a female predominance with a male female sex ratio of 0.6: 1 . Most of the participants presented with vertebral bone pain $45(72.58 \%)$, followed by asthenia $40(64.52 \%)$ and weight loss $11(17.74 \%)$ as shown on Table 1.

\begin{tabular}{|c|c|c|c|}
\hline \multicolumn{2}{|c|}{ Characteristic } & Frequency & Percentage \\
\hline \multirow{4}{*}{ Age distribution } & $<45$ & 4 & 6.5 \\
\cline { 2 - 4 } & $45-54$ & 22 & 35.5 \\
\cline { 2 - 4 } & $55-64$ & 18 & 29 \\
\cline { 2 - 4 } & $65-74$ & 14 & 22.6 \\
\cline { 2 - 4 } & $75-84$ & 4 & 6.4 \\
\hline \multirow{3}{*}{ Performance status } & 0 & 20 & 32.3 \\
\cline { 2 - 4 } & 1 & 15 & 24.2 \\
\cline { 2 - 4 } & 2 & 15 & 24.2 \\
\hline
\end{tabular}




\begin{tabular}{|l|c|c|c|}
\hline & 3 & 12 & 19.4 \\
\hline \multirow{4}{*}{ Clinical characteristics } & Low back pain & 45 & 72.6 \\
\cline { 2 - 4 } & Asthenia & 40 & 64.5 \\
\cline { 2 - 4 } & Inability to work & 15 & 24.2 \\
\cline { 2 - 4 } & Weight loss & 11 & 17.5 \\
\cline { 2 - 4 } & Fever & 10 & 16.1 \\
\cline { 2 - 4 } & Loss of sensation & 5 & 8.1 \\
\cline { 2 - 4 } & Insomnia & 2 & 3.2 \\
\cline { 2 - 4 } & Rib pain & 4 & 6.5 \\
\cline { 2 - 4 } & Abdominal pain & 4 & 6.4 \\
\cline { 2 - 4 } & Bone swelling & 2 & 3.2 \\
\hline
\end{tabular}

Table 1: Sociodemographic and clinical characteristics of the participants at diagnosis

\section{Biological characteristics}

\begin{tabular}{|c|c|c|c|}
\hline Laboratory investigation & Classification & Frequency & Percentage \\
\hline Haemoglobin & Haemoglobin $<10.5$ & 44 & 80 \\
\hline$(n=62$ & Haemoglobin $\geq 10.5$ & 18 & 20 \\
\hline ESR at $1^{\text {st }}$ hour & $\leq 20$ & 2 & 9.1 \\
\hline$(n=44)$ & $>20 \mathrm{~mm}$ & 40 & 90.9 \\
\hline \multirow{2}{*}{ Medullar plasmocyte percentage $(n=42)$} & $\leq 10$ & 3 & 7.1 \\
\hline & $>10$ & 39 & 92.9 \\
\hline \multirow{2}{*}{ Total proteins $g / L(n=55)$} & $50-80$ & 20 & 36.4 \\
\hline & $>80$ & 35 & 63.6 \\
\hline \multirow{2}{*}{ Immunoglobulins } & IgG & 13 & 86.7 \\
\hline & $\operatorname{IgA}$ & 2 & 13.3 \\
\hline \multirow{4}{*}{ Gamma globulins (n 56) } & $<8$ & 2 & 3.6 \\
\hline & Aug-18 & 7 & 12.5 \\
\hline & $19-30$ & 16 & 28.6 \\
\hline & $30-100$ & 31 & 55.4 \\
\hline \multirow{2}{*}{ Bence jones proteinuria $(n=10)$} & Positive & 2 & 20 \\
\hline & Negative & 8 & 80 \\
\hline \multirow[t]{2}{*}{ Serum albumin $(n=55)$} & $<35$ & 33 & \\
\hline & Raised & 22 & 73.3 \\
\hline Serum $\beta-2$ microglobulin $(n=30)$ & Normal & 8 & 26.6 \\
\hline \multirow{2}{*}{ Serum calcium $(n=51)$} & Hypercalcaemia & 13 & 25.5 \\
\hline & Normal calcium & 38 & 74.5 \\
\hline \multirow[t]{2}{*}{ c-reactiveprotein $(n=39)$} & $>6 \mathrm{mg} / \mathrm{L}$ & 25 & 64.1 \\
\hline & $\leq 6$ & 14 & 35.9 \\
\hline \multirow{3}{*}{$\mathrm{LDH}$} & $<160 I U / 1$ & 3 & 15 \\
\hline & $160-320 I U / 1$ & 12 & 60 \\
\hline & $>320 \mathrm{IU} / \mathrm{l}$ & 5 & 25 \\
\hline \multirow{2}{*}{ Creatinine $(n=55)$} & $\geq 170 \mu \mathrm{mol} / \mathrm{L}$ & 41 & 74.6 \\
\hline & $<170 \mu \mathrm{mol} / \mathrm{L}$ & 14 & 25.4 \\
\hline
\end{tabular}

Table 2: Laboratory findings in the participants at diagnosis

The following laboratory features were observed; the mean haemoglobin concentration at diagnosis was $9.37 \pm 2.79 \mathrm{~g} / \mathrm{dl}$ with a range of $4.0-16.3 \mathrm{~g} / \mathrm{dl}$, $44(70.9 \%)$ patients were anaemic with haemoglobin less than $10.5 \mathrm{~g} / \mathrm{dl}$ (Table 2). The mean total white cell count was $9.62 \pm 15.01(2.0-8.1) \times 103$, platelets was
$238.98 \pm 151.14(41-941)$, serum albumin was 34.09 $\pm 9.63(11.27-60.5)$, and serum $\beta-2$ microglobulin was $15.85 \pm 19.03$ (0.14 - 78.20). About 13(86.66\%) participants had Immunoglobulin $G$ and $22(73.33 \%)$ and had raised $\beta-2$ microglulin levels. 
Radiological and Imaging Characteristics

\begin{tabular}{|c|c|c|}
\hline Radiological finding & Frequency & Percentage \\
\hline Pathologic fracture & 7 & 14.9 \\
\hline Bone demineralization & 21 & 44.7 \\
\hline Lytic lesions & 27 & 57.5 \\
\hline Spinal cord compression & 22 & 46.8 \\
\hline
\end{tabular}

Table 3: Radiological and imaging characteristics of the participants at diagnosis

Most common radiological and or imaging finding was bone demineralisations in 21 (44.7\%) participants as shown on table III. Lytic lesions were observed in 27(57.45\%) participants. 7 (14.9) participants had pathological fractures distributed as follows: 3 cases of vertebral fractures, 4 cases of fracture of the femoral neck and 1 case of humeral fracture.

\section{Diseases Activity}

Diseases activity was classified using the Durie and Salmon classification. $48(61.2 \%)$ of the participants were found to be at stage three of the disease at the time of diagnosis as shown on Figure 1.

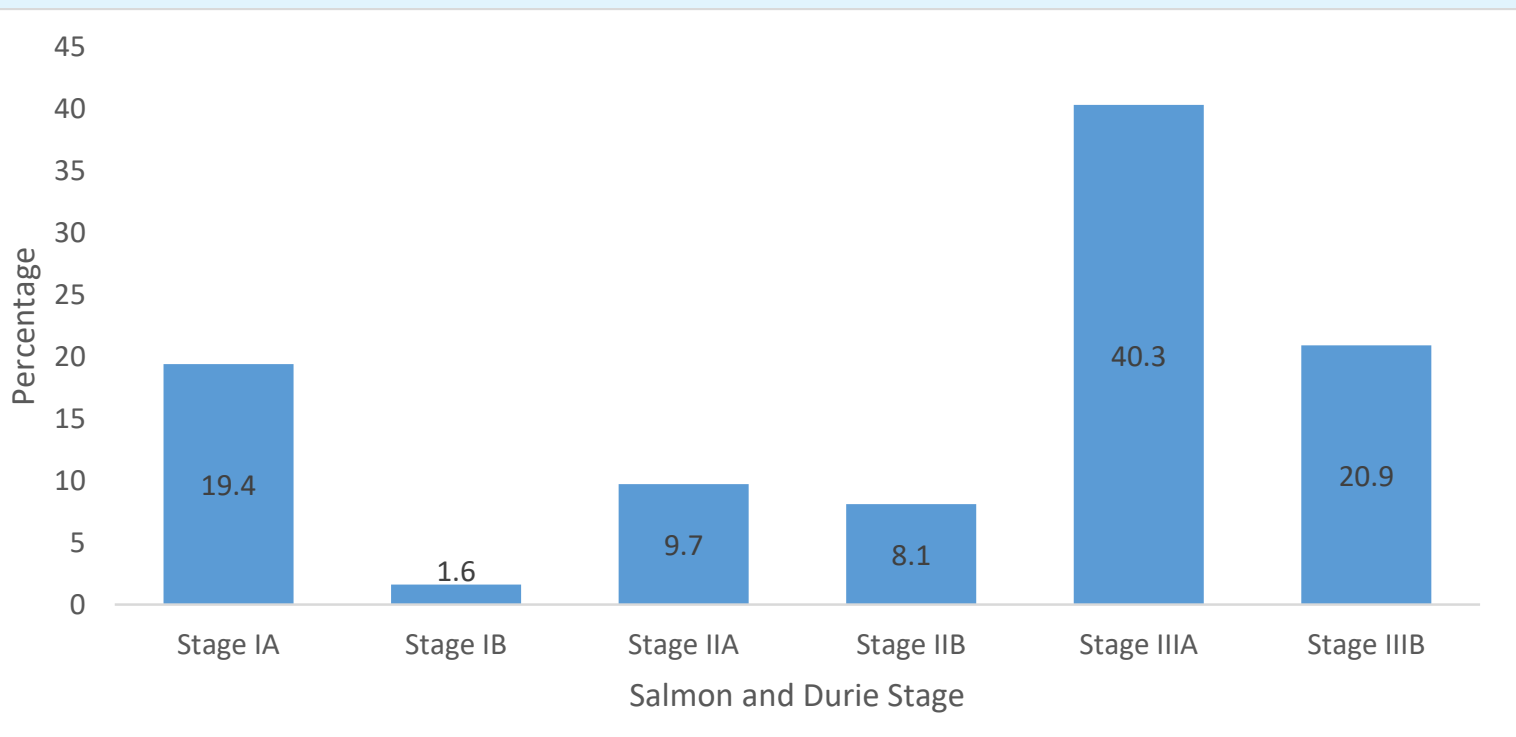

Figure 1: Classification of multiple myeloma using Durie and Salmon Classification at the time of diagnosis.

\section{Discussion}

Multiple myeloma is an age long haematological malignancy that progresses insidiously, this cross sectional describes clinico-biological and imaging characteristics of patients with $\mathrm{MM}$ in a tertiary care setting in Cameroon. This index study described herein revealed an average of 10-11 cases per year. The mean age at presentation in the the index study is $57.6 \pm 12.2$ years and these patients present with various complications such as bone pain, fracture, cord compression, anaemia and renal failure. 10-11 cases diagnosed per annum in our hospital is far greater than 4 observed in a recent study in Nigeria [13]. This could be explained by the fact that the hospital is one of the biggest reference hospital in the sub region and as such received cases from most other hospitals within the central African sub region. Our mean age of 57 years is quite similar to that obtained from similar studies in Cameroon [14] and Nigeria $[13,15,16]$. The female predominance of $63 \%$ given a male female ratio of $0.6: 1$ shows that this disease affects more females than males. This contradicted by recent studies that show either a male predominance [15] or a ratio of male female slightly equal [17].

Majority of our patients presented with low back pains. This finding is similar to that reported by recently in Cameroon in the same hospital by DouallaBija, et al. [14]. Several studies in Nigeria $[6,13,15,18]$ and in the western world by Talamo, et al. [12]. The pattern of presentation in our study clearly depicts late presentation as most of the patients presented with one or more complications. These complications included anaemia (80.0\%), hypercalcaemia (25.5\%), renal failure $(25.4 \%)$ and pathological fractures (14.9\%). The high prevalence of anaemia in our index study is similar to that obtained in studies in Nigeria $[13,15]$. Likewise the percentage of pathological is similar to that obtain by Madu et al in Nigeria in 2014 [15]. Greater than $90 \%$ of our participants had an erythrocyte sedimentation rate (ESR) greater than $20 \mathrm{~mm} / \mathrm{h}$ during the first hour. The elevated ESR is consistent with other studies $[13,15]$, further 
demonstrating late diagnosis of MM in our hospital. Elevated ESR in these patients also demonstrate poor prognosis [18]. About a quarter of our patients had hypercalcemia, this has been shown to be associated with pathological fractures and poor prognosis [18]. Similarly, about quarter of the patients had raised serum creatinine greater than $15 \mathrm{mg} / \mathrm{l}$. nephropathy in multiple myeloma is an independent factor of mortality $[2,15,18]$.

The majority $(60 \%)$ of those who had records of serum protein electrophoresis had hypoalbuminemia, with a mean serum albumin level of $34.09 \mathrm{mg} / \mathrm{dl}$. While hyperproteinaemia is a factor of survival, hypoproteinaemia and hypoalbuminemia are independent factors of mortality and poor prognosis [15]. Further, $73.3 \%$ of the participants had raised beta-2-microglobulin levels. Raised levels of serum beta-2-microglobulin are associated with poor prognosis [13,15]. Immunoglobulin $G$ was found to occur more commonly than other immunoglobulins on immunofixation. This is similar to studies done by Nwabuko et al [6] where IgG was the major immunoglobulin but different from that of Madu, et al. [15] where IgA was more common. This explains the immunoglobulin variations in multiple myeloma. IgG has been described to be associated to poor prognosis compared to other immunoglobulins [6].

Most of the patients38 (6.2\%) were diagnosed with myeloma at stage III of DS of the disease. This is similar to studies recently published in 2017 by Nwabuko, et al. [6] where most patients presented with stage III diseases. This further confirms the assertion that most patients presented late in our indexed study. Presentation in stage IIIA and IIIB has been shown to be an independent factor of mortality and to be associated with poor prognosis $[6,15,18]$.

Though the index study described herein has described importantclinico-biological characteristics of multiple myeloma in a resource-low setting, some of the major limitations to the use of the results include: It cross sectional nature and hence failure to describe determinants, treatment and outcome (survival and mortality) not described, it retrospective nature. Despite these limitations, this study will serve as a pilot study for future studies on MM in Cameroon.

\section{Conclusion}

Multiple myeloma is relative more common in our hospital than described in literature with $10-11$ cases diagnosed per annum. It presents in the 5th - 6th decade of life, more common in females than in males. Most patients present with already established complications of the diseases such as fracture, renal failure and hypercalcemia. Sensitization of personnel and patients may be an important step to curb this growing problem

\section{Declarations}

Ethics approval and consent to participate: Ethical approval was obtained from the institutional review board of the Faculty of Health Sciences, University of Buea, Cameroon. A copy of is available for review upon request by the Editor-in-Chief of this journal.

Consent for publication: Not applicable Availability of data and material: The data sets supporting the conclusion of this study are contained within the study.

Competing interests: "The authors declare that they have no competing interests" in this section.

Funding: None

Author's contributions: EDTN: She conceived the ideas and wrote this article, MSD: Supervised the work and edited the article, PNT: Edited and wrote the final English version of the manuscript; GE: edited the work; DTO: wrote the protocol, collected and analyzed data, wrote the initial draft of the article, NRB: edited the work and review the final manuscript; DM: Edited the work and provided general supervision

Acknowledgement: We express our sincere gratitude to all the patients who took part in this study.

\section{References}

1. Kyle RA, Gertz MA, Witzig TE, Lust JA, Lacy MQ, et al. (2003) Review of 1027 Patients With Newly Diagnosed Multiple Myeloma. Mayo Clin Proc 78(1): 21-33.

2. Fasola FA, Eteng KII, Shokunbi WA, Akinyemi JO, Salako BL (2012) Renal Status of Multiple Myeloma Patients In Ibadan, Nigeria. Ann Ib Postgrad Med 10(2): 28-33.

3. Jemal A, Siegel R, Ward E, Hao Y, Xu J, et al. (2009) Cancer statistics, 2009. CA Cancer J Clin 59(4): 225-249.

4. Benjamin M, Reddy S, Brawley OW (2003) Myeloma and race: a review of the literature. Cancer Metastasis Rev 22(1): 87-93.

5. Kristinsson SY, Björkholm M, Goldin LR, Blimark C, Mellqvist UH, et al. (2009) Patterns of hematologic malignancies and solid tumors among 37,838 firstdegree relatives of 13,896 multiple myeloma 
patients in Sweden. Int J Cancer J Int Cancer 125(9): 2147-2150.

6. Nwabuko OC, Igbigbi EE, Chukwuonye II, Nnoli MA (2017) Multiple myeloma in Niger Delta, Nigeria: complications and the outcome of palliative interventions. Cancer Manag Res 9: 189-196.

7. Alexander DD, Mink PJ, Adami H-O, Cole P, Mandel JS, et al. (2007) Multiple myeloma: a review of the epidemiologic literature. Int J Cancer 12: 40-61.

8. Weiss BM, Abadie J, Verma P, Howard RS, Kuehl WM (2009) A monoclonal gammopathy precedes multiple myeloma in most patients. Blood 113(22): 5418-5422.

9. Pérez-Persona E, Vidriales M-B, Mateo G, GarcíaSanz R, Mateos M-V, et al. (2007) New criteria to identify risk of progression in monoclonal gammopathy of uncertain significance and smoldering multiple myeloma based on multiparameter flow cytometry analysis of bone marrow plasma cells. Blood 110(7): 2586-2592.

10. Kyle RA, Rajkumar SV (2004) Multiple myeloma. N Engl J Med 351(18): 1860-1873.

11. Waxman AJ, Mink PJ, Devesa SS, Anderson WF, Weiss BM, et al. (2010) Racial disparities in incidence and outcome in multiple myeloma: a population-based study. Blood Dec 116(25): 55015506.

12. Talamo G, Farooq U, Zangari M, Liao J, Dolloff NG, et al. (2010) Beyond the CRAB symptoms: a study of presenting clinical manifestations of multiple myeloma. Clin Lymphoma Myeloma Leuk 10(6): 464-468.

13. Olaniyi JA, Fowodu FO (2015) Multiple myeloma: The burden and clinico-laboratory characteristics in a Nigerian foremost tertiary hospital. J Appl Hematol 6(2): 58-63.

14. Doualla-Bija M, Ndongho EN, Oben DT, Namme HL, Mbanya D (2014) Musculoskeletal Presentation of Multiple Myeloma At General Hospital Douala, Cameroon. East Afr Med J 91(9): 311-316.

15. Madu AJ, Ocheni S, Nwagha TA, Ibegbulam OG, Anike US (2014) Multiple myeloma in Nigeria: an insight to the clinical, laboratory features, and outcomes. Niger J Clin Pract 17(2): 212-217.

16. Salawu L, Durosinmi MA (2005) Myelomatosis: Clinical and laboratory features in Nigerians. West Afr J Med 24(1): 54-57.

17. Kristinsson SY, Landgren O, Dickman PW, Derolf AR, Bjorkholm M (2007) Patterns of survival in multiple myeloma: a population-based study of patients diagnosed in Sweden from 1973 to 2003. J Clin Oncol 25(15): 1993-1999.

18. Nnonyelum ON, Anazoeze MJ, Eunice NO, Emmanuel 00, Stella AT, et al. (2015) Multiple myeloma in Nigeria: a multi-centre epidemiological and biomedical study. Pan Afr Med J 22: 292. 